\title{
Detection and distribution of Ophelimus migdanorum and its possible biocontroller Closterocerus chamaeleon in productive areas of Eucalyptus globulus in Chile
}

\author{
Gloria Molina-Mercader ${ }^{1,2 *}$, Andrés O. Angulo ${ }^{3}$, Eugenio Sanfuentes ${ }^{1}$, Rodrigo Hasbún ${ }^{1}$, \\ Tania Olivares ${ }^{3}$, Miguel Castillo-Salazar ${ }^{1}$, and Claudio Goycoolea ${ }^{4}$ \\ 'Universidad de Concepción, Facultad de Ciencias Forestales, Casilla 160-C, Concepción, Chile. \\ ${ }^{2}$ MIPlagas Ltda., 1973 Av. Las Rosas, Huertos Familiares, San Pedro de La Paz, Concepción. \\ "Corresponding author (gloria.molina@miplagas.cl). \\ ${ }^{3}$ Universidad de Concepción, Facultad de Ciencias Naturales y Oceanográficas, Casilla 160-C, Concepción, Chile. \\ ${ }^{4}$ Consorcio de Protección Fitosanitaria Forestal, Av. María Dolores 3580, Los Ángeles, Chile.
}

Received: 24 November 2018; Accepted: 8 April 2019; doi:10.4067/S0718-58392019000300337

\begin{abstract}
Wasps that belong to the genus Ophelimus develop galls on Eucalyptus spp., and E. globulus is considered among the most susceptible species. In 2003, a new species of Ophelimus was detected in Chile. This species forms galls on $E$. globulus and E. camaldulensis, and it was recently considered as Ophelimus migdanorum nov sp. The present study was carried out $16 \mathrm{yr}$ after its detection and it was aimed to determine the presence of Ophelimus in plantations of $E$. globulus located in Maule, Biobío and La Araucanía Regions, which represent 76\% of the area covered with this species in the country. Between August and September 2017, a total of 165 sampling forest farms were established in stands of E. globulus, located in these regions of the country. In each farm, twigs were collected that represented formation of galls and maintained in laboratory conditions until the emergence of adults. These were identified according to their external morphological characteristics. The presence of $O$. migdanorum and Closterocerus chamaeleon was determined. Both species emerged together in all the regions considered in the study, $92.1 \%$ and $46.7 \%$ of the evaluated forest farms, respectively. Then Ophelimus migdanorum is widely distributed in Maule, Biobío and La Araucanía Regions, in Chile.
\end{abstract}

Key words: Biocontroller, Eucalyptus spp., gall-maker, galls, Ophelimus.

\section{INTRODUCTION}

The cultivation of species of the genus Eucalyptus has increased strongly in the world due to its economic, industrial and ornamental interest, reaching an approximate area of 20 million hectares by 2013 (Wingfield et al., 2013). In Chile, the area planted with Eucalyptus spp. amounts 860317 ha, in which E. globulus participates in 68.8\% (INFOR, 2018).

The genus Ophelimus (Haliday, 1844) has approximately 50 species associated to the production of galls on different species of Eucalyptus (La Salle et al., 2009). Among these, only two species have been documented: Ophelimus maskelli (Ashmead) (Hymenoptera: Eulophidae) (Protasov et al., 2007a) and Ophelimus eucalypti Gahan (Hymenoptera: Eulophidae) (Gahan, 1922; Withers et al., 2000; La Salle, 2005). Both species are native to Australia (La Salle, 2005) and have been dispersed to different countries outside their natural distribution. Ophelimus maskelli has been reported in Israel (Protasov et al., 2007a), South Africa, New Zealand (Branco et al., 2016), Vietnam, Indonesia (Lawson et al., 2012); Tunisia (Dhahri et al., 2010) South Africa (Hurley, 2014), Turkey (Doganlar and Mendel, 2007), Italy (Arzone and 
Alma, 2000), Spain (Sánchez, 2003), France (European and Mediterranean Plant Protection Organization, 2006), Portugal (Branco et al., 2009), Greece (Kavallieratos et al., 2006; Branco et al., 2016), Argentina (Aquino et al., 2014), USA (Burks et al., 2015) and Crinea (Nikulina and Martynov, 2018). On the other hand, Ophelimus eucalypti has been determined in New Zealand (Withers et al., 2000), Iran, Morocco, Kenya, Uganda (Arzone and Alma, 2000; Sánchez, 2003; PujadeVillar and Riba-Flinch, 2004).

Among the host species of O. maskelli and O. eucalypti,E.globulus, E camaldulensis Dehnh. and E. saligna Sm., are described (Protasov et al., 2007a; CABI/EPPO, 2011). For O. eucalypti, E. botryoides Sm., has been indicated as host (CABI/EPPO, 2011) and in the case of O. maskelli, E. tereticornis Sm., E. grandis W. Hill ex. Maiden and E. gunnii Hook. f., have been mentioned in addition to other nine species of economic importance (Protasov et al., 2007a).

Defoliations of economic significance attributable to Ophelimus have been reported in several countries. In Israel, Mendel et al. (2007) reported high population irruptions of $O$. maskelli causing almost total defoliations in adult Eucalyptus trees with densities high enough as to interrupt daily human activities and even, harvesting other crops (Burks et al., 2015). On the other hand, O. eucalypti has been described causing serious damages in New Zealand (Withers et al., 2000) on E. globulus, making impossible to grow it commercially (Valentine, 1963; Wilson, 1963). In addition, this has also been observed in Iran, Morocco, Kenya and Uganda (Maina, 2003; Sánchez, 2003) in both E. camaldulensis and $E$. globulus (Pujade-Villar and Riba-Flinch, 2004).

In 2004, the Hymenoptera Closterocerus chamaeleon Girault (Eulophidae) was detected parasitizing O. maskelli (Mendel et al., 2007; Borrajo et al., 2008). Closterocerus chamaeleon is widely described as ectoparasitoid (Borrajo et al., 2008), condition that may not be applicable to all its stages of development, since has been determined in mature larval stage and in pupal tissue from $O$. maskelli (Protasov et al., 2007b). It is unknown if the parasitic behavior of $C$. chamaeleon corresponds to a koinobiont or idiobiont. However, it has been estimated that due to its wide range of body size, but narrow variation in development time, this parasitoid would correspond rather to the idiobiont type. This added to the ectoparasitoid condition could reflect a narrow group of hosts for this species (Protasov et al., 2007b). The known host range of this parasitoid wasp is limited to O. maskelli, but it is possible that other gall-inducing species in Eucalyptus leaves also serve as hosts (Protasov et al., 2007b; Burks et al., 2015).

This parasitoid micro-wasp has been detected in Algeria, Australia, France, Israel, Italy, Portugal, Spain, Tunisia, Turkey (Noyes, 2013) and Argentina (Aquino et al., 2014). Closterocerus chamaeleon is parthenogenetic, with a short lifecycle $\left(3\right.$ wk at $\left.25^{\circ} \mathrm{C}\right)$, has winter activity and a high dispersion capacity. These features provide the species a high potential as biocontroller (Borrajo et al., 2008). This parasitoid was introduced from Australia to be used in classical biological control programs of $O$. maskelli in Israel (2005-2006) and Italy (2006). In both countries, the control results were successful (Laudonia et al., 2006; Protasov et al., 2007b; Mendel et al., 2007; Caleca et al., 2011; Mendel et al., 2017; Suma et al., 2018).

Ophelimus sp. was detected for the first time in Chile in 2003 in the Valparaiso Region, forming galls on E. globulus and E. camaldulensis (SAG, 2006), being later reported in 2009 in the Province of Cauquenes, Maule Region (MolinaMercader, 2019; unpublished data). In 2010, in a joint work between Molina-Mercader, Dr. John La Salle (CSIROAustralia) and the Agricultural and Livestock Service of Chile it was confirmed that the gall wasp detected in the country corresponded to a species of the genus Ophelimus, different from O. maskelli and O. eucalypti (La Salle, 2010, personal communication), being identified through $O$. migdanorum (Molina-Mercader, 2019; unpublished data).

In this context and due the significant economic burden E. globulus represent for the Chilean forest industry, we aimed to determine the presence of Ophelimus migdanorum in plantations of E. globulus located between the Maule, Biobío and La Araucanía Regions, Chile.

\section{MATERIALS AND METHODS}

The study was carried out between July and August 2017 in plantations of E. globulus located between the Regions of Maule ( $35^{\circ} 25^{\prime} 36^{\prime \prime} \mathrm{S}, 71^{\circ} 40^{\prime} 18^{\prime \prime} \mathrm{W}$ ) and La Araucanía (38 $\left.54^{\prime} 00^{\prime \prime} \mathrm{S}, 72^{\circ} 40^{\prime} 00^{\prime \prime} \mathrm{W}\right)$. These regions cover $76 \%$ of the area established with this forest species in the country (INFOR, 2018) (Table 1). 
Table 1. Forest farms in the Maule, Biobío and La Araucanía Regions, in which samples of Eucalyptus globulus twigs with galls were detected.

\begin{tabular}{lcc}
\hline Region & Sampled farms (Nr) & Area of Eucalyptus globulus (ha) \\
\hline Maule & 26 & 45420 \\
Biobío & 93 & 247967 \\
La Araucanía & 46 & 156487 \\
Total & 165 & 449874 \\
\hline
\end{tabular}

\section{Field sampling}

The sampling was carried out in stands of E. globulus older than $2 \mathrm{yr}$. The selection of the forest farms was performed considering the distribution range of E. globulus in the regions under study. To this end, a network of points was arranged on a plane that contained the distribution of the target plantations, on which the farms to be sampled were selected, considering an average intensity of sampling of one stand every 2726 ha. In those cases, in which there were no plantations older than $2 \mathrm{yr}$ in the selected farm, it was replaced by the nearest farm. In total, 165 farms were selected (Table 1). Sampled farms were georeferenced and indicated in a map made using Google Earth (Table 1).

A total of three trees that presented formation of gall were selected in each farm, considering a separation of five trees between each one. From each selected tree, a twig of approximately $50 \mathrm{~cm}$ length measured from the distal part of the twig towards the stem was extracted. On the other hand, the samples were taken from the lower third of the tree. These samples were placed in polyethylene bags of $30 \times 40 \mathrm{~cm}$, with absorbent paper, labeled and then sent to the laboratory of MIPlagas Ltda., located in the commune of San Pedro de La Paz, Concepción, in the Biobío Region, Chile, to be analyzed.

\section{Laboratory breeding, adult emergence and species identification}

The collected twigs were placed in breeding chambers, one per chamber, with a total of 495 chambers. The chamber consisted of a transparent plastic box $(20 \times 30 \times 40 \mathrm{~cm})$ with cover, on whose base, two sheets of absorbent paper were installed. Each breeding chamber was sealed with film paper and kept in the laboratory until the emergence of adults, at a temperature that ranged between 18 and $22{ }^{\circ} \mathrm{C}$, approximately $60 \% \mathrm{RH}$, and $16: 8 \mathrm{~h}$ photoperiod. Breeding chambers were revised every day and the absorbent paper was changed every other day to avoid contamination (Figure 1a).

The insects that emerged from the breeding chambers were collected in Petri dishes and subsequently fixed in 96\% ethanol, in screw-cap tubes for cryo-preservation (Figure 1b).

The identification of each of the individuals was performed based on morphological characteristics and using descriptions available for O. maskelli (Protasov et al., 2007a), C. chamaeleon (Protasov et al., 2007b) and for O. migdanorum (MolinaMercader et al., 2019; unpublished data).

The identified specimens were counted and registered according to the breeding chamber and sampled farm, to be then fixed in $90 \%$ ethanol in cryopreservation tubes. Photographs were taken at 40X (B-1000 microscope, OPTIKA, Ponteranica, Italy) at MIPlagas laboratory.

\section{Indicators of dispersion and abundance of species}

The frequency of each species was determined, considering the relative participation of the positive farms to the presence of a certain species of insect, and respect to the total quantity of farms sampled in each region, expressed as a percentage in the following expression:

Frequency of farms $(\%)=(\mathrm{Nr}$ positive farms in region/ $\mathrm{Nr}$ sampled farms in the regions $) \times 100$

Additionally, the population density at species and region level was estimated, considering the individuals of each species collected in the region and the totality of positive farms to the presence of each species, using the following expression:

Individuals by farms $(\mathrm{Nr})=(\mathrm{Nr}$ individuals collected in the region/ $\mathrm{Nr}$ positive farms in the region $)$

Both standard error and significance in each region was estimated, using the MIXED procedure to means of incidence of pests ( $\mathrm{p} \leq$ 0.05) (1996, SAS Institute, Cary, North Carolina, USA). 
Figure 1. (a) Breeding chambers with leaves of Eucalyptus globulus, and their disposition in the laboratory of MIPlagas Ltda. (b) Tube with screw cap for storage of specimens of Ophelimus migdanorum. (c) Adults of O. migdanorum in Petri dishes.

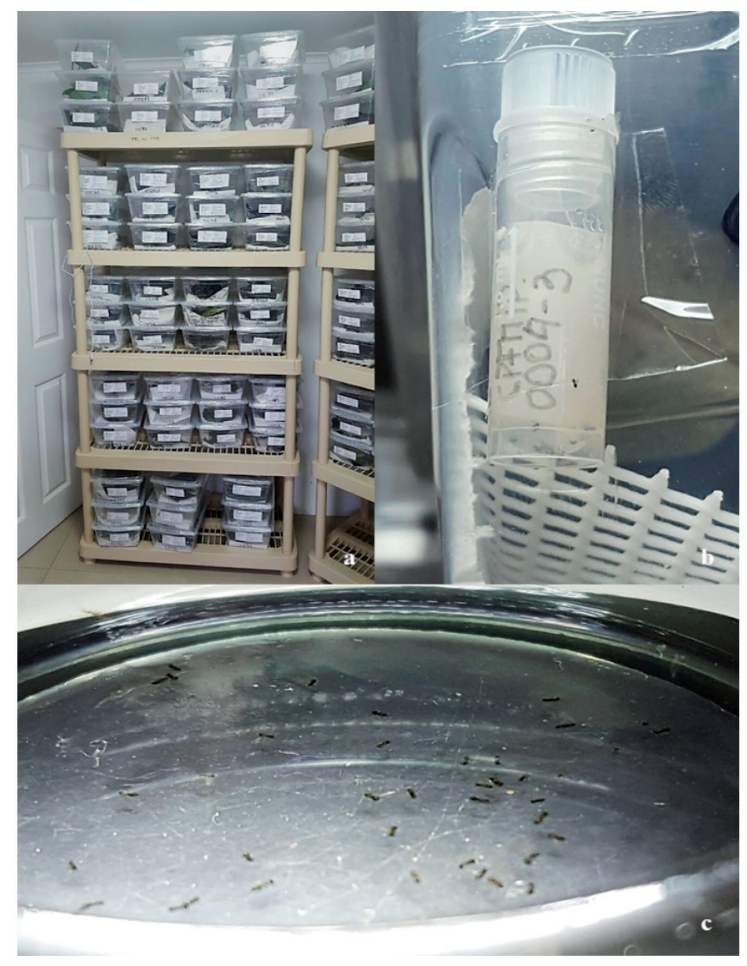

\section{RESULTS}

The presence of the species $O$.migdanorum and the parasitoid $C$. chamaeleon was determined in each of the three regions evaluated. The individuals that emerged from the breeding chambers during the study period corresponded to 14152 and 927 individuals of $O$. migdanorum and C. chamaeleon, respectively (Table 2).

During the identification procedure of the species it was determined that the eye color and the shape of the abdomen were an effective tool to distinguish between individuals of $O$. migdanorum and $C$. chamaeleon (Figure 2, Table 3). This preliminary distinction coincided in $100 \%$ of the cases with the complete morphological identification for everyone.

Ophelimus migdanorum was determined in 152 farms, equivalent to $92.1 \%$ of the total farms sampled in the present study. On the other hand, $C$. chamaeleon was found in $46.7 \%$ of the farms ( 77 farms), coinciding in all cases with those farms in which $O$. migdanorum was detected. The emergence of $C$. chamaeleon together with the gall wasp was observed in $99.1 \%$ of the breeding chambers. Only in one chamber in La Araucanía Region and another in the Biobío Region there was the emergence of only specimens of $C$. chamaeleon (Figure 3). In both cases, from the other three breeding chambers that completed the sample of each farm in each of these regions, the emergence of both species was obtained.

Table 2. Individuals of Ophelimus migdanorum and Closterocerus chamaeleon emerged by region.

\begin{tabular}{lcc}
\hline Region & Ophelimus migdanorum & Closterocerus chamaeleon \\
\hline Maule & 872 & 21 \\
Biobío & 7.955 & 487 \\
La Araucanía & 5.325 & 419 \\
Total & 14.152 & 927 \\
\hline
\end{tabular}


Figure 2. Morphological differences between Closterocerus chamaeleon and Ophelimus migdanorum: (a) Red eyes and lanceolate abdomen in C. chamaeleon; (b) black eyes and rounded abdomen in $O$. migdanorum.

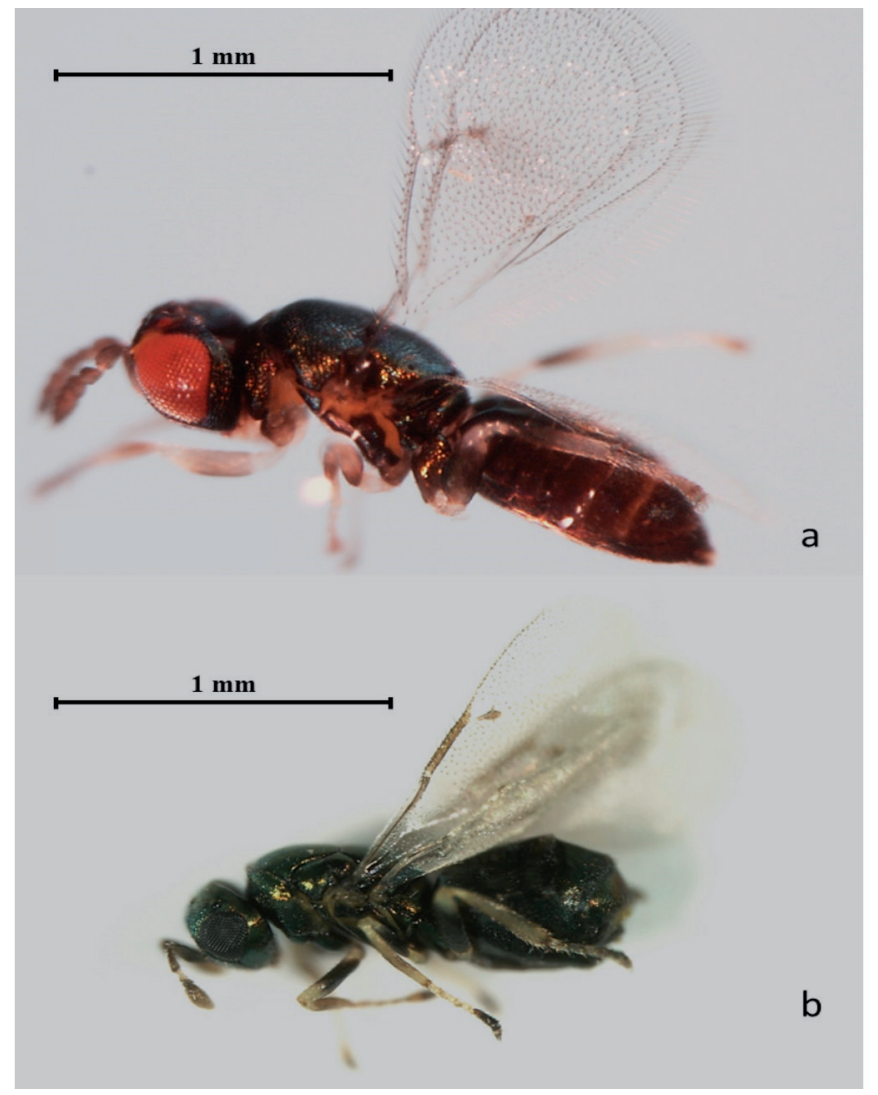

Table 3. Main characteristics for visual identification of specimens of Ophelimus migdanorum and Closterocerus chamaeleon.

\begin{tabular}{llc}
\hline Charecteristic & Ophelimus migdanorum & Closterocerus chamaeleon \\
\hline Eyes & $\begin{array}{l}\text { The same tone as the } \\
\text { body (Figure 2b) }\end{array}$ & Red (Figure 2a) \\
Abdomen & Rounded (Figure 2b) & Lanceolate (Figure 2a) \\
\hline
\end{tabular}

The highest frequency of farms positive to O. migdanorum was observed in the Biobío Region and corresponded to $97.8 \%$ and only in two farms located in the north coast this region, the O. migdanorum was not detected. The parasitoid C. chamaeleon was determined at lower levels than the gall wasp, ranging between $47.9 \%$ and 53.8\%, in Biobío and La Araucanía Regions, respectively. On the other hand, in the Maule Region the lowest frequency was registered, being observed its presence in $19.2 \%$ of the farms evaluated (Figure 4).

The average population level of $O$. migdanorum for the three regions was 87.0 (individuals in 3 twigs per farm), whereas in the case of $C$. chamaeleon was 11.1. The population levels of both species varied between regions, being increased from north to south (with significant differences only for $O$. migdanorum in La Araucanía Region). The lowest population values were found in the Maule Region, located in the north of the study area and the highest values were found in La Araucanía Region, located further south (Figure 3, Table 4). Differences between population levels and the estimations of the north respect to the south were $33.5 \%$ and $22.1 \%$ for O. migdanorum and C. chamaeleon, respectively. 
Figure 3. Distribution of sampling farms in the Maule, Biobío and La Araucanía Regions. Triangle indicates the presence of Ophelimus migdanorum. Circle indicates detection of $O$. migdanorum and Closterocerus chamaeleon. Pushpin indicates no emergence. This map was elaborated in Google Maps.

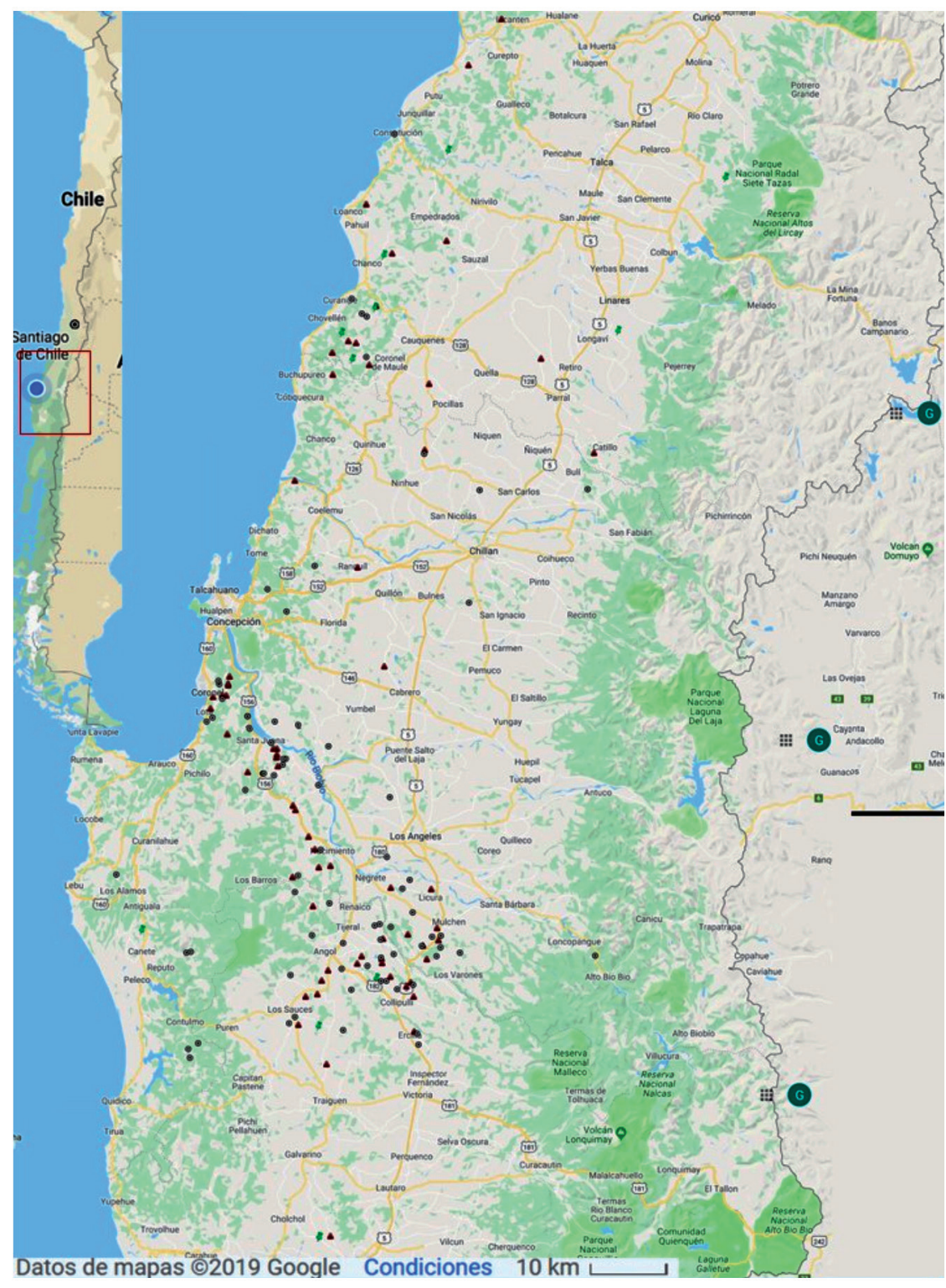

\section{DISCUSSION}

The presence of $O$. migdanorum and $C$. chamaeleon were determined in Chile in the three regions evaluated in the study, Maule, Biobío and La Araucanía, emerging from galls formed in juvenile and adult twigs of E. globulus. Ophelimus migdanorum was found in the three regions evaluated, in $92.1 \%$ of the farms, with a population level of 87.0 individuals, in 3 twigs per stand (Figure 3, Table 3). This would indicate its establishment in localities of the country where the plantations of E. globulus are concentrated. This represents a phytosanitary threat to the sustainability of the cultivation of this species, together with the effects of Gonipterus platensis, detected in the country in 1998 (Beéche, 1999). Both level and type of damage was not evaluated in this study. However, during the field sampling, gall formation was observed in succulent stems, petiole, blade and midribs associated with death of leaves, twigs and even complete trees. This coincides with observations carried out by Bain (1977) in New Zealand for damage caused by O. eucalypti on E. globulus (Figure 5). 
Figure 4. Frequency of farms positive (presence) to Ophelimus migdanorum and Closterocerus chamaeleon per region.

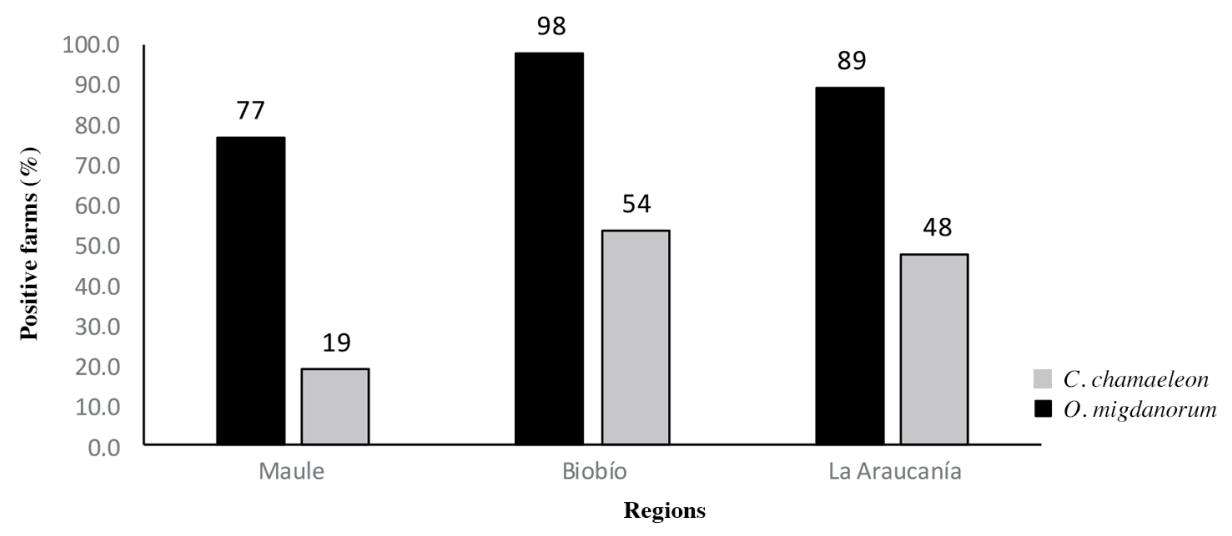

Table 4. Average population of Ophelimus migdanorum and Closterocerus chamaeleon per region, obtained from three twigs per farm.

\begin{tabular}{lcc}
\hline & \multicolumn{2}{c}{ Individuals $(\mathrm{Nr})$} \\
\cline { 2 - 3 } Region & Ophelimus migdanorum & Closterocerus chamaeleon \\
\hline Maule & $43.6 \pm 8.4 \mathrm{~b}$ & $4.2 \pm 1.2 \mathrm{a}$ \\
Biobío & $87.4 \pm 9.8 \mathrm{~b}$ & $9.9 \pm 2.3 \mathrm{a}$ \\
La Araucanía & $129.9 \pm 23.2 \mathrm{a}$ & $19.0 \pm 6.4 \mathrm{a}$ \\
Total & $87.0 \pm 24.9$ & $11.1 \pm 4.3$ \\
\hline
\end{tabular}

Values in parentheses indicate standard error.

Different letters indicate significant differences between regions $(\mathrm{p} \leq 0.05)$.

The formation of galls in petioles or twigs in repetitive attacks would lead to a decrease in the growth capacity of the twigs by a loss of leaves of terminal twigs, death of the twigs when larger twigs are attacked, decreased growth of adult and young trees and finally the death of the tree (Bain, 1977; Pujade-Villar and Riba-Flinch, 2004; Suma et al., 2018). In Chile, in a seed orchard of E. globulus it was observed during 2017 the formation of galls on capsules, associated with Botryosphaeria sp., which induces the abortion of such capsules, being estimated loss of up to $50 \%$ in the seed production (Molina-Mercader, 2019; unpublished data). According to Branco et al. (2016), regarding the adult of $O$. maskelli, it increases its survival when it feeds on eucalyptus flowers compared to those cases in which only drinking water.

The regions with the highest frequency and population density of $O$. migdanorum corresponded to Biobío and La Araucanía, which concentrated $68.3 \%$ (404 $454 \mathrm{ha)}$ of the area planted with E. globulus established in the country (INFOR, 2018).

The determination of $C$. chamaeleon in the farms evaluated at a presence level of $46.7 \%$ would indicate its establishment in Chile, in the three regions prospected. Closterocerus chamaeleon has not been introduced in Chile to be used in biological control programs, so its dispersion could have occurred naturally. Among the capabilities described for the wasp, its dispersion capacity can be highlighted. This capacity is favored by the wind, given its reduced size can travel between 100 and $120 \mathrm{~km} \mathrm{~d}^{-1}$ in favorable wind conditions (Protasov et al., 2007b). In Israel, it was estimated that the wasp travelled $120 \mathrm{~km}$ in a period of 10 to 12-mo (Protasov et al., 2007b). On the other hand, in Turkey in 2007 it was determined its transfer from Israel, at $1500 \mathrm{~km}$ (Doganlar and Mendel, 2007). Branco et al. (2009) pointed out that the dispersion of this insect in the southern Mediterranean area is favored by the high density of its host $O$. maskelli on E. camaldulensis. In this context and considering that in his study the highest levels of $C$. chamaeleon coincide with the region with the largest population of $O$. migdanorum (Figure 3, Table 4), the hypothesis that the parasitoid wasp is advancing in its colonization process of the study area from south to north cannot be ruled out. This is supported by the fact of the continuity of the cultivation of E. globulus and the dispersion of $O$. migdanorum. 
Figure 5. Ophelimus migdanorum on petiolate spring leaf (a); cut in gall twig showing 6 larvae/5 mm gall, 40X (b); dead branch (c); adult insect emerging from Eucalyptus globulus floral capsule, 40X (d); twig with galls and adult emergency orifice of $O$. migdanorum (e); sessile leaf with galls and emergency holes (f).

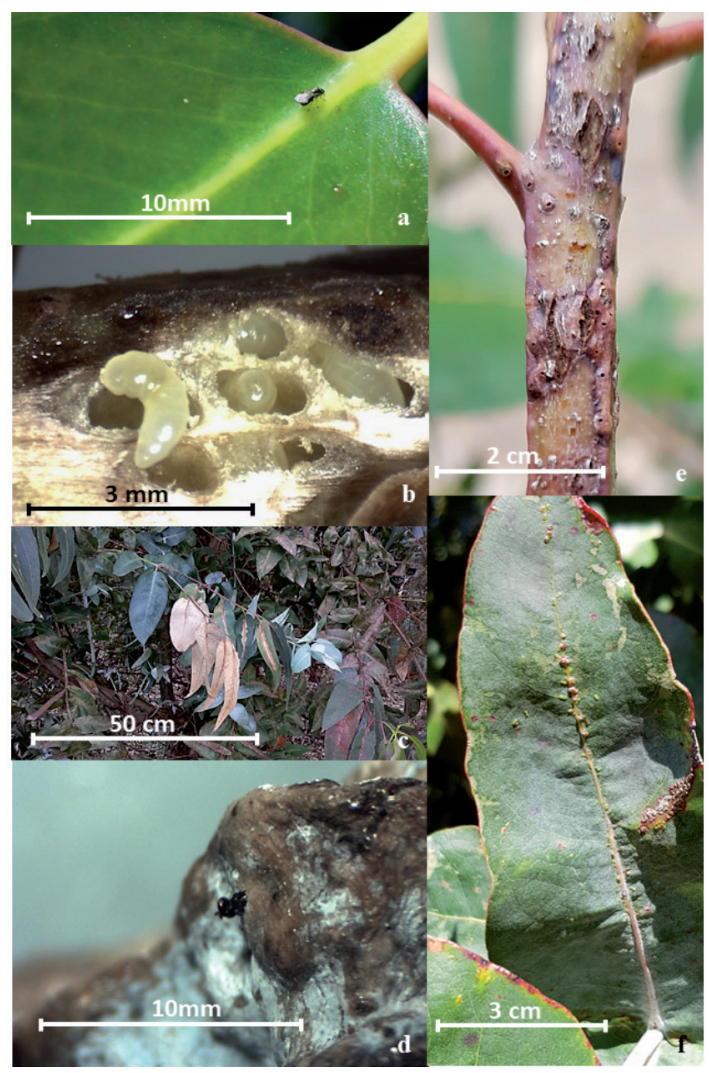

In Chile, pests such as Rhyacionia buoliana (Schiff) and Sirex noctilio F., have moved forward from south to north, affecting Pinus radiata D. Don. Rhyacionia buoliana was detected in Los Ríos Region in 1985 and in the Biobío Region in 1991, located $500 \mathrm{~km}$ to the north (Lanfranco et al., 1991).

The frequency at stand level and population density of $C$. chamaeleon estimated in this study were lower than those of O. migdanorum. Once the high dispersion potential of $C$. chamaeleon has been known, this could indicate that the natural introduction to the country would be more recent than O. migdanorum, which was reported in 2003 as Ophelimus sp. (SAG, 2006).

In this work it was not possible to accurately determine the parasitism of $C$. chamaeleon on O. migdanorum. However, since this species was determined emerging with $O$. migdanorum in $100 \%$ of the cases from the same farms and from the same twig in $99.1 \%$ of the breeding chambers, it is possible to propose the hypothesis that $C$. chamaeleon could be performing a parasitic role on $O$. migdanorum. It reinforces the previous approach, the occurrence in collected leaves, of galls with necrosis and others without necrosis, in the first case as action of the phytophagous.

Closterocerus chamaeleon is a recognized parasitoid of O. maskelli (Floris et al., 2018), though Protasov et al. (2007b) indicate that it is possible that other species of the gall-inducing Ophelimus in leaves of Eucalyptus can also serve as hosts. In this study, the emergence of $O$. maskelli was not obtained from the breeding chambers, nor its presence been reported in Chile (Aquino et al., 2015). Further studies are required around this matter, working for instance at the level of gall dissection to identify the species present.

The morphological characteristics of eyes and abdomen used to differentiate $O$. migdanorum from $C$. chamaeleon was effective in $100 \%$, which represents a valuable practical tool in the laboratory, particularly considering the abundance of the populations of these insects. Additionally, the reflected color was used, showing a light metallic green color for $C$. chamaeleon and its way of walking different from that of O. migdanorum. 
The determination of $C$. chamaeleon in this study constitutes the first reference for the country, in productive areas of $E$. globulus. Its finding could represent, in the case of being found its parasitic condition on $O$.migdanorum, a contribution to the sanitary sustainability of the cultivation of E. globulus in the country. Likewise, this could be the first determination C. chamaeleon, like possible biocontroller of $O$. migdanorum in the world.

\section{CONCLUSIONS}

Ophelimus migdanorum is widely distributed in Maule, Biobío and La Araucanía Regions, in Chile.

\section{ACKNOWLEDGEMENTS}

The authors thank the support by the owners of forest farms partners of the Phytosanitary Protection Consortium Inc. and MIPlagas Ltda. for providing the access to the places in order to carry out the samplings and contribute or perform the collection of the samples of twigs affected by the pest. Special thanks to Dr. John LaSalle (in memoriam) for his permanent motivation and entomological support. Authors also thank the staff of MIPlagas, for turning their work into a passion for the well-being of the forests of their clients. To my friend Sandra Ide for reviewing and contributing with this work.

\section{REFERENCES}

Aquino, D.A., Hernández, C.M., Cuello, E.M., Andorno, A.V., y Botto, E.N. 2014. Primera cita de la Argentina de Ophelimus maskelli (Ashmead) (Hymenoptera: Eulophidae) y su parasitoide, Closterocerus chamaeleon (Girault) (Hymenoptera: Eulophidae) Revista de la Sociedad Entomológica Argentina 73(3-4):179-182.

Aquino, D.A., Hernández, C.M., Cuello, E.M., Andorno, A.V., y Botto, E.N. 2015. Errata: Primera cita de la Argentina de Ophelimus maskelli (Ashmead) (Hymenoptera: Eulophidae) y su parasitoide, Closterocerus chamaeleon (Girault) (Hymenoptera: Eulophidae). Revista de la Sociedad Entomológica Argentina 74(1-2):97.

Arzone, A., e Alma, A. 2000. Eulofide galligeno dell'Eucalipto in Italia. Informatore Fitopatologico 12:43-46.

Bain, J. 1977. Ophelimus spp. Forest and timber insects in New Zealand. Nr 15. 2 p. Scion, Rotorua, New Zealand. Available at https://www.scionresearch.com/__data/assets/pdf_file/0020/3944/Ent15Ophelimussp.pdf (accessed 2003).

Beéche, M. 1999. Programa de detección y control del gorgojo del eucalipto, Gonipterus scutellatus (Gyll.) (Coleoptera: Curculionidae). p. 33-34. In Libro de Actas XXI Congreso Nacional de Entomología, Arica. 3-5 Noviembre. Universidad de Tarapacá, Arica, Chile.

Borrajo, P., López A., Ocete R., López G., y Ruíz F. 2008. Primera cita de Closterocerus chamaeleon (Girault) (Hymenoptera, Eulophidae), parasitoide de Ophelimus maskelli Ashmead (Hymenoptera, Eulophidae) en la Provincia de Huelva (SO España). Boletín de Sanidad Vegetal Plagas 34:383-385.

Branco, M., Battisti, A., and Mendel, Z. 2016. Foliage feeding invasive insects: Defoliators and gall makers. Paine, T.D., and Lieutier, F. (eds.) Insects and diseases of Mediterranean forest systems. Springer International Publishing, Cham, Switzerland. doi:10.1007/978-3-319-24744-1_8.

Branco, M., Boavida, C., Durand, N., Franco, J., and Mendel, Z. 2009. Presence of the Eucalyptus gall wasp Ophelimus maskelli and its parasitoid Closterocerus chamaeleon in Portugal: First record, geographic distribution and host preference. Phytoparasitica 37:51-54. doi:10.1007/s12600-008-0010-7.

Burks, R.A., Mottern, J.L., Waterworth, R., and Paine, T. 2015. First report of the Eucalyptus gall wasp, Ophelimus maskelli (Hymenoptera: Eulophidae), an invasive pest on Eucalyptus, from the Western Hemisphere. Zootaxa 3926(3):448-450.

CABI/EPPO. 2011. Ophelimus eucalypti. [Distribution map]. Distribution maps of plant pests. Nr December. Map 756. CABI, Wallingford, UK.

Caleca, V., Lo Verde, G., Rizzo, M.C., and Rizzo, R. 2011. Dispersal rate and parasitism by Closterocerus chamaeleon (Girault) after its release in Sicily to control Ophelimus maskelli (Ashmead) (Hymenoptera, Eulophidae). Biological Control 57:66-73.

Dhahri, S, Ben Jamaa, M., and Lo Verde, G. 2010. First record of Leptocybe invasa and Ophelimus maskelli eucalyptus gall wasps in Tunisia. Tunisian Journal of Plant Protection 5:229-234.

Doganlar, M., and Mendel,Z. 2007. First record of the eucalyptus gall wasp Ophelimus maskelli, and its parasitoid, Closterocerus chamaeleon, in Turkey. Phytoparasitica 35:333-335.

European and Mediterranean Plant Protection Organization. 2006. First report of two new eucalyptus pests in the south of France Ophelimus maskelli and Leptocybe invasa. EPPO Reporting Service 9:2006/189 European and Mediterranean Plant Protection Organization (EPPO), Paris, France.

Floris, I., Buffa F., Cocco A., and Mannu, R. 2018. Insect pests of Eucalyptus plantations in Sardinia (Italy). Journal of Zoology 101:61-71. 
Gahan, A.B. 1922. A list of phytophagous Chalcidoidea with descriptions of two new species. Reprinted from the Proceedings of the Entomological Society of Washington 24. № 2. February 1922.

Hurley, B. 2014. New pest of Eucalyptus detected in South Africa. Available at http://www.fabinet.up.ac.za/index.php/newsitem?id=136 (accessed 21 February 2015).

INFOR. 2018. Anuario forestal. Boletín Estadístico N 163. p. 1-19. Instituto Forestal (INFOR), Santiago, Chile.

Kavallieratos, N.G., Kontodimas, D.C., Anagnou-Veroniki, M., and Emmanouel, N.G. 2006. First record of the gall-inducing insect Ophelimus eucalypti (Gahan) (Hymenoptera: Chalcidoidea: Eulophidae) in Greece. Annals of the Benaki Phytopathological Institute. Nouvelle Serie 20:125-128.

La Salle, J. 2005. Biology of gall inducers and evolution of gall induction in Chalcidoidea (Hymenoptera: Eulophidae, Eurytomidae, Pteromalidae, Tanaostigmatidae, Torymidae). p. 507-537. In Raman, A., Schaefer, C.W., and Withers, T.M. (eds.) Biology, ecology, and evolution of gall-inducing arthropods. Science Publishers, Enfield, New Hampshire, USA.

La Salle, J., Arakelian, G., Garrison, R.W. and Gates, M.W. 2009. A new species of invasive gall wasp (Hymenoptera: Eulophidae: Tetrastichinae) on blue gum (Eucalyptus globulus) in California. Zootaxa 2121:35-43.

Lanfranco, D.M., Büchner, J., Aguilar, M.A., y Horcos, R. 1991. Parasitoides nativos en el control de la polilla del brote del pino (Rhyacionia buoliana): avances en la identificación del complejo y de sus estrategias de desarrollo. Bosque 12(1):69-74.

Laudonia, S., Viggiani, G., e Sasso, R. 2006. Nuova introduzione in Italia. Parassitoide esotico in aiuto degli eucalipti. Informatore Agrario 40:74 (in Italian).

Lawson, S., Griffiths, M., Nahrung, H., Noack, A., Wingfield, M., Wilcken, C., et al. 2012. Biological control of eucalypt pests overseas and in Australia. Final report number FST/2011/028. Australian Centre for International Agricultural Research, Canberra, Australia.

Mendel, Z., Protasov, A., Blumberg, D., Brand, D., Saphir, N., Madar, Z., et al. 2007. Release and recovery of parasitoids of the Eucalyptus gall wasp Ophelimus maskelli in Israel. Phytoparasitica 35(4):330-332. http://dx.doi.org/10.1007/BF02980694.

Mendel, Z., Protasov, A., La Salle, J., Blumberg, D., and Branco, M. 2017. Classical biological control of two Eucalyptus gall wasps; main out come and conclusions. Biological Control 105:66-78

Nikulina, T., and Martynov, V. 2018. Ophelimus maskelli (Ashmead, 1900) (Hymenoptera: Eulophidae) - a new invasive pest of eucalyptus in Crimea. Subtropical and Ornamental Horticulture 67:217-226. doi:10.31360/2225-3068-2018-67-217-226.

Noyes, J.S. 2013. Universal Chalcidoidea Database. Available at http://www.nhm.ac.uk/entomology/chalcidoids/index.htlm (accessed 25 March 2014).

Protasov, A., Blumberg, D., Brand, D., La Salle, J., and Mendel, Z. 2007b. The basis for biological control of the eucalyptus gall wasp Ophelimus maskelli (Ashmead): taxonomy and biology of the parasitoid Closterocerus chamaeleon (Girault), with information on its establishment in Israel. Biological Control 42:196-206.

Protasov, A., La Salle, J., Blumberg, D., Brand, D., Saphir, N., Assael, F., et al. 2007a. Biology, revised taxonomy and impact on host plants of Ophelimus maskelli, an invasive gall inducer on Eucalyptus spp. in the Mediterranean area. Phytoparasitica 35(1):50-76.

Pujade-Villar, J., y Riba-Flinch, J. 2004. Dos especies australianas de eulófidos, muy dañinas para Eucalyptus spp., introducidas en el nordeste ibérico (Hymenoptera: Eulophidae). Boletín de la Sociedad Entomológica Aragonesa 35:299-301.

SAG. 2006. Informativo Fitosanitario Año 2. N³. Servicio Agrícola y Ganadero de Chile (SAG), Santiago, Chile. Available at http://www.sag.cl/sites/default/files/informativo_3.pdf (accessed March 2006).

Sánchez, I. 2003. Descubiertas dos nuevas plagas del eucalipto en España. Quercus 214:32-33.

Suma, P., Nucifora, S., Caleca, V., Lo Verde, G., Tortorici, F., Rapisarda, C., et al. 2018. A review on introduced alien insect pests and their associated parasitoids on eucalyptus trees in Sicily. Journal of Zoology 101:81-88.

Valentine, E.W. 1963. A list of the phytophagous Hymenoptera in New Zealand. New Zealand Entomologist 4:52-62.

Wilson, F. 1963. Australia as source of beneficial insects for biological control. Technical Bulletin of the Commonwealth Institute of Biological Control 3:1-28.

Wingfield, M., Roux, J., Slippers, B., Hurley, B., Garnas, J., Myburg, A., et al. 2013. Established and new technologies reduce increasing pest and pathogen threats to Eucalypt plantations. Forest Ecology and Management 301:35-42.

Withers, T.M., Raman, A., and Berry, J.A. 2000. Host range and biology of Ophelimus eucalypti (Gahan) (Hym.: Eulophidae), a pest of New Zealand Eucalypts. New Zealand Plant Protection 53:339-344. 